\title{
Formation of Ozone in Urban Air by Photochemical Oxidation of Hydrocarbons: Captive Air Experiments in Porto Alegre, RS
}

\author{
Eric Grosjean, and Daniel Grosjean \\ DGA, Inc., 4526 Telephone Road, Suite 205, Ventura, CA 93003 USA
}

Received: September 12, 1997

Experimentos em ar capturado foram realizados em uma área do centro da cidade em Porto Alegre, RS, onde tanto metil-tert-butil éter (MTBE) quanto etanol são utilizados como combustíveis oxigenados. Nesse tipo de experimento, o ar ambiente é introduzido em uma câmara de Teflon e exposto à luz do sol por várias horas, permitindo assim que reações fotoquímicas se processem em condições que reproduzem a realidade. Entre os parâmetros medidos em seis experimentos, os primeiros do gênero a serem realizados no Brasil, incluem-se óxidos de nitrogênio ( $\mathrm{NO}_{\text {e }} \mathrm{NO}_{2}$ ), monóxido e dióxido de carbono, metano, cerca de 75 hidrocarbonetos não metânicos, formaldeído, acetaldeído, etanol, MTBE e os oxidantes fotoquímicos ozônio e nitrato de peroxiacetila (PAN).

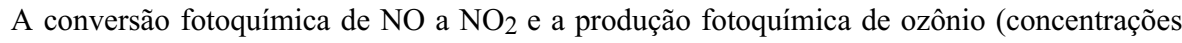
máximas de 156 a 348 ppb) e PAN (máximo de 13,3 a 29,5 ppb) foi observada em todos os experimentos, junto à produção fotoquímica líquida (formação menos remoção) de formaldeído e acetaldeído. Para cada experimento, foram calculadas as contribuições de cada poluente para a reação com o radical hidroxil $(\mathrm{OH})$ e para a produção de ozônio. Os resultados indicam que, na média, os 10 compostos a seguir são os mais importantes com respeito à produção de ozônio (listados em ordem decrescente de importância): etileno, monóxido de carbono, acetaldeído, $(\mathrm{m}+\mathrm{p})$-xileno, formaldeído, propeno, 1,2,4-trimetilbenzeno, tolueno, etanol e trans-2-penteno. O MTBE fornece apenas uma pequena contribuição à reação com o radical $\mathrm{OH}$ (\#27 no ranking), e à produção de ozônio (\#30 no ranking), desempenhando assim um papel menor na fotoquímica da atmosfera de Porto Alegre.

Captive air experiments have been carried out at a downtown location in Porto Alegre, RS, where both methyl-tert-butyl ether (MTBE) and ethanol are being used as oxygenated fuels. In a captive air experiment, ambient air is introduced in a Teflon chamber and exposed to sunlight for several hours, thus allowing photochemical reactions to take place under "real-world" conditions. Parameters measured in six experiments, the first of their kind to be carried out in Brazil, included oxides of nitrogen ( $\mathrm{NO}$ and $\mathrm{NO}_{2}$ ), carbon monoxide, carbon dioxide, methane, $c a$. 75 non-methane hydrocarbons, formaldehyde, acetaldehyde, ethanol, MTBE, and the photochemical oxidants ozone and peroxyacetyl nitrate (PAN).

Photochemical conversion of $\mathrm{NO}$ to $\mathrm{NO}_{2}$ and photochemical production of ozone (maximum concentrations 156-348 ppb) and PAN (maximum 13.3-29.5 ppb) were observed in all experiments, together with net (formation minus removal) photochemical production of formaldehyde and acetaldehyde. For each experiment, the contributions of each pollutant to reaction with the hydroxyl radical $(\mathrm{OH})$ and to the production of ozone have been calculated. The results indicate that on the average the following 10 compounds are the most important with respect to the production of ozone (listed in order of decreasing importance): ethylene, carbon monoxide, acetaldehyde, $(m+p)$-xylene, formaldehyde, propene, 1,2,4-trimethylbenzene, toluene, ethanol and trans-2-pentene. MTBE makes only a small contribution to reaction with $\mathrm{OH}$ (ranked \#27) and to the production of ozone (ranked \#30), and plays only a minor photochemical role in the atmosphere of Porto Alegre.

Keywords: urban air pollution, oxygenated fuels, ozone formation, captive air studies, hydrocarbon reactivity ranking, ethanol, methyl-tert-butyl ether 


\section{Introduction}

Emissions from stationary and mobile sources have adverse effects on urban air quality. Primary pollutants are emitted directly into the atmosphere. Major primary pollutants include carbon monoxide, oxides of nitrogen $\left(\mathrm{NO}_{\mathrm{x}}\right)$, volatile organic compounds (VOC) and particulate matter. Primary pollutants, including VOC and $\mathrm{NO}_{\mathrm{x}}$, may be oxidized in-situ in the atmosphere in a series of complex, sunlight-initiated chemical reactions. The corresponding reaction products are called secondary pollutants and include ozone, peroxyacyl nitrates, carbonyls, carboxylic acids and secondary aerosols. The most studied of these secondary pollutants is ozone ${ }^{1}$, for which Brazil, like many other countries, has issued a national ambient air quality standard.

Since ozone forms in the atmosphere by reactions involving $\mathrm{VOC}$ and $\mathrm{NO}_{\mathrm{x}}$, control strategies for ozone air quality must involve control of the emissions of the primary pollutants that are precursors to ozone, namely VOC and $\mathrm{NO}_{\mathrm{x}}$. The necessary first steps when assessing ozone air quality in a given urban area are to identify VOC, to measure their concentrations, and to measure $\mathrm{NO}_{\mathrm{x}}$ concentrations. These measurements have been recently performed as part of a one-year study conducted in the metropolitan Porto Alegre area ${ }^{2,3}$. Once information is available regarding urban $\mathrm{VOC}$ and $\mathrm{NO}_{\mathrm{x}}$, it becomes possible using computer air quality models $\mathrm{s}^{4,5}$, to estimate how much ozone will form in $\mathrm{VOC}-\mathrm{NO}_{\mathrm{x}}$ reactions during atmospheric transport downwind of the urban center.

Captive air experiments may provide useful information regarding how much ozone may form by $\mathrm{VOC}-\mathrm{NO}_{\mathrm{x}}$ reactions in a given urban area. In a captive air experiment, ambient air containing VOC and $\mathrm{NO}_{\mathrm{x}}$ is introduced in a reaction vessel (smog chamber) and is exposed to sunlight for several hours. In this "captive" air parcel, all the chemical reactions that lead to ozone formation in the atmosphere are taking place, but there is no dilution and no addition of VOC and $\mathrm{NO}_{\mathrm{x}}$ during transport, i.e., meteorology and pollutant emissions along the trajectory of the air parcel have been deleted. Therefore, the amount of ozone formed in a captive air experiment gives a measure of the amount of ozone that would be produced by photochemical reactions of the VOC and $\mathrm{NO}_{\mathrm{x}}$ initially present in the same air parcel in the atmosphere. In addition to providing a direct measure of the photochemical reactivity of a given air parcel, the results of captive air experiments can be used as input to computer modeling simulations of the effects of emission controls (VOC control, $\mathrm{NO}_{\mathrm{x}}$ control, or both) on urban levels of ozone. Captive air experiments have been carried out in several cities in the U.S. including Houston, Texas $^{6}$, Detroit, Michigan ${ }^{7}$, and Los Angeles, California ${ }^{8,9}$. In Japan, this approach has led to the design and construction of a mobile smog chamber $^{10}$ which could be used to carry out captive air experiments at several urban locations. Captive air experiments have not been carried out in Brazil prior to this study, which also includes the first detailed report of ambient concentrations of $c a .75 \mathrm{VOC}$ in the atmosphere of a Brazilian city.

The objective of this article is to describe captive air experiments carried out in Porto Alegre, RS, where both MTBE and ethanol are being used as oxygenated fuels. The captive air experiments involved sunlight irradiation of a parcel of ambient air at a downtown location where ambient levels of pollutants have been extensively characterized $^{2,3}$. Six experiments have been carried out, each involving a different, "real-world" mixture of ambient VOC and ambient $\mathrm{NO}_{\mathrm{x}}$. In each experiment, initial concentrations of the following ozone precursors were measured: speciated VOC ( $c a .75$ compounds including MTBE and ethanol), oxides of nitrogen ( $\mathrm{NO}$ and $\mathrm{NO}_{2}$ ), carbon monoxide $(\mathrm{CO})$, and the aldehydes formaldehyde $(\mathrm{HCHO})$ and acetaldehyde $\left(\mathrm{CH}_{3} \mathrm{CHO}\right)$. Continuous measurements were made of $\mathrm{NO}, \mathrm{NO}_{2}$ and ozone, thus yielding concentrationtime profiles that documented the photochemical conversion of $\mathrm{NO}$ to $\mathrm{NO}_{2}$ and the formation of ozone. Peroxyacetyl nitrate ( $\mathrm{PAN}, \mathrm{CH}_{3} \mathrm{C}(\mathrm{O}) \mathrm{OONO}_{2}$ ), another important photochemical oxidant, was measured along with ozone in these experiments. The results are discussed with focus on assessing the relative importance of VOC (including MTBE and ethanol) as precursors to ozone in the Porto Alegre urban area. The results of the captive air experiments, together with those of other studies ${ }^{2,3}$ may also serve as input to computer modeling studies of ozone air quality in Porto Alegre.

\section{Experimental Methods}

The captive air experiments were carried out at the Rodoviaria monitoring station ${ }^{2,3}$ in downtown Porto Alegre. The monitoring station was located a few blocks from the center of town on a $30 \mathrm{~m}$ wide divider strip in the middle of a major highway that brings a large fraction of the vehicle traffic to and from the center of Porto Alegre. The monitoring station was also near a major bus terminal. In a typical experiment, ambient air was introduced in a smog chamber constructed from FEP 200A Teflon film. This type of Teflon film is transparent to sunlight over the spectrum of wavelengths relevant to tropospheric photochemical reactions. Wall losses of ozone, hydrocarbons, $\mathrm{NO}_{\mathrm{x}}, \mathrm{PAN}$ and other pollutants in chambers made of FEP 200A film have been characterized in detail in previous studies $^{11-13}$. The initial volume of the chamber was $c a .3 .7$ $\mathrm{m}^{3}$. The ambient air was introduced in the chamber during the period of high vehicle traffic as indicated by measurements of ambient levels of the two primary pollutants carbon monoxide (measured with a Dasibi 3008 continuous analyzer, gas filter correlation spectroscopy method) and nitric oxide (API 200A continuous analyzer, chemilumi- 
nescence method). The contents of the chamber were then exposed to sunlight.

At the beginning of each experiment, samples were collected to measure initial VOC and initial aldehyde concentrations. Samples for VOC were collected in electropolished stainless steel canisters. The sampling duration was $c a$. one minute. The canisters were returned to the laboratory and their contents were analyzed for $\mathrm{CO}, \mathrm{CO}_{2}$ and for $c a$. 75 VOC including MTBE and ethanol. These analyses involved a combination of methods including gas chromatography with flame ionization detection (GC-FID) and gas chromatography-mass spectrometry (GC-MS). Samples for aldehydes were collected on $\mathrm{C}_{18}$ cartridges coated with 2,4-dinitrophenylhydrazine (DNPH). The sampling duration was one hour. Formaldehyde and acetaldehyde were measured as their DNPH derivatives by liquid chromatography (LC) with ultraviolet detection. One field control cartridge was analyzed along with the batch of samples. The GC-FID, GC-MS and DNPH-LC methods have been described in detail elsewhere ${ }^{2,3,14}$.

Oxides of nitrogen ( $\mathrm{NO}$ and $\mathrm{NO}_{2}$ ) were measured by chemiluminescence (API 200A analyzer). Ozone was measured by ultraviolet photometry (Dasibi $1108 \mathrm{AH}$ analyzer). PAN was measured by gas chromatography with electron capture detection as described previously ${ }^{15}$. The $\mathrm{NO}_{x}$, ozone and PAN analyzers were connected to the Teflon sampling port of the chamber using $0.6 \mathrm{~cm}$ diameter Teflon sampling lines. The operation and data acquisition protocols for these instruments and the corresponding cali- brations have been described previously ${ }^{2,3}$. The precision of the measurements was $\pm 1-2$ ppb for ozone, $\pm 3-5$ ppb for $\mathrm{NO}$ and $\mathrm{NO}_{2}$ and $\pm 30 \%$ for PAN. Temperature was recorded every $30 \mathrm{~min}$ during the experiments. Sunlight irradiations were carried out for typically 5-6 h. The experiments were terminated shortly after the maximum in ozone concentration had been recorded. A second set of one-hour aldehyde samples was collected near the end of each experiment. The smog chamber was then emptied and cleaned by flushing several times (typically 3 times) with high purity air (using a cylinder of zero grade air) prior to the start of the next captive air experiment.

\section{Results and Discussion}

\section{Photochemical formation of $\mathrm{NO}_{2}$, ozone and PAN}

Six captive air experiments have been carried out. A summary of initial concentrations, maximum ozone and PAN concentrations and other relevant information is given in Table 1. Initial $\mathrm{NO}_{\mathrm{x}}\left(\mathrm{NO}+\mathrm{NO}_{2}\right)$ concentrations ranged from 110 to $233 \mathrm{ppb}$. The initial $\mathrm{NO} / \mathrm{NO}_{2}$ concentration ratios (ppb / ppb) ranged from 0.83 to 2.64. Examples of concentration-time profiles for $\mathrm{NO}, \mathrm{NO}_{2}$, ozone and PAN are shown in Fig. 1 for experiment \#4 and in Fig. 2 for experiment $\# 5$. These profiles show, as expected, conversion of $\mathrm{NO}$ to $\mathrm{NO}_{2}$ and formation of the photochemical oxidants ozone and PAN. The maximum ozone concentrations ranged from 156 to $348 \mathrm{ppb}$, and the maximum PAN concentrations ranged from 13.3 to $29.5 \mathrm{ppb}$.

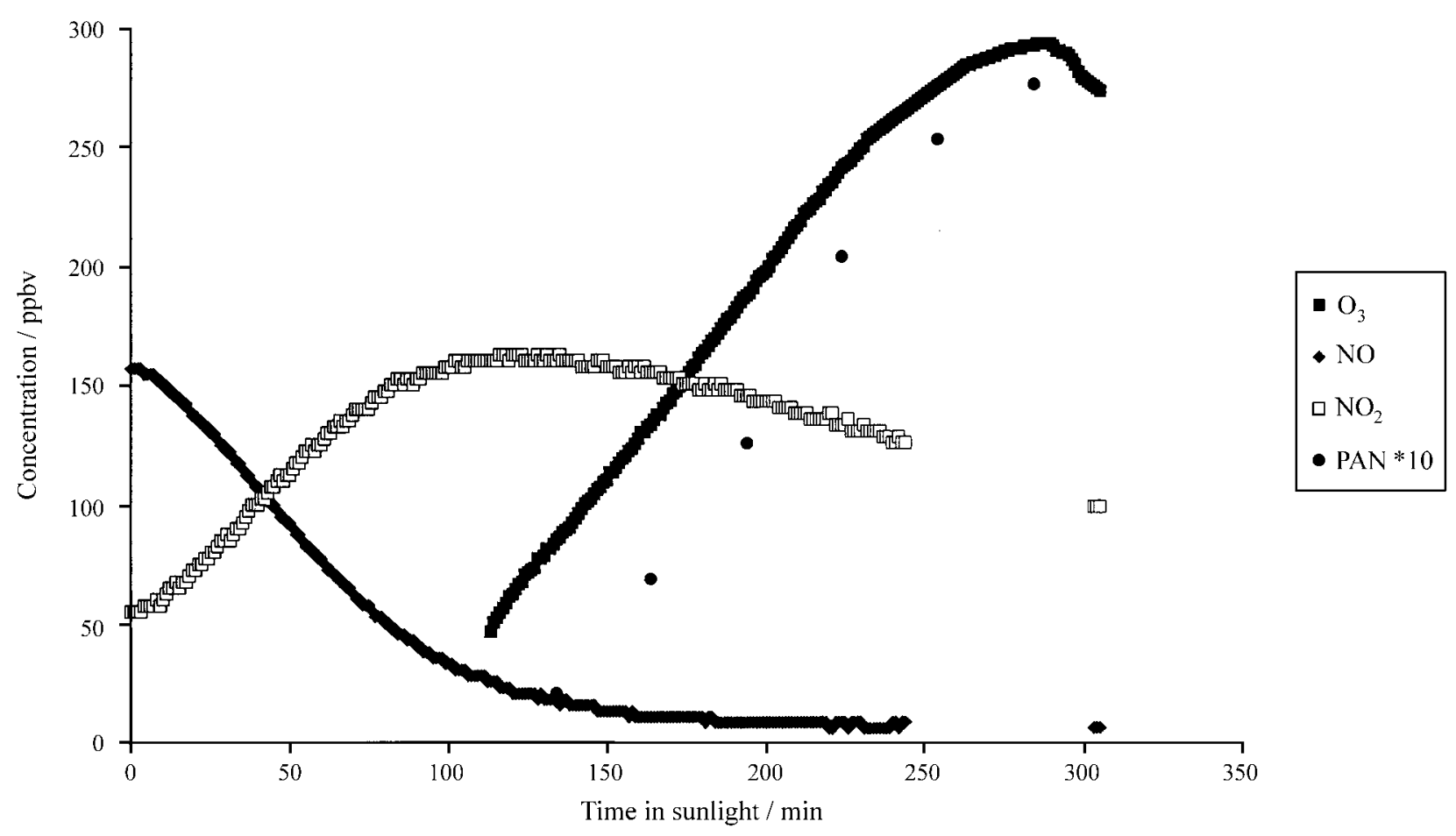

Figure 1. Concentrations of $\mathrm{NO}, \mathrm{NO}_{2}$, ozone and $\mathrm{PAN}$ in captive air experiment \#4 (April 14, 1997). 


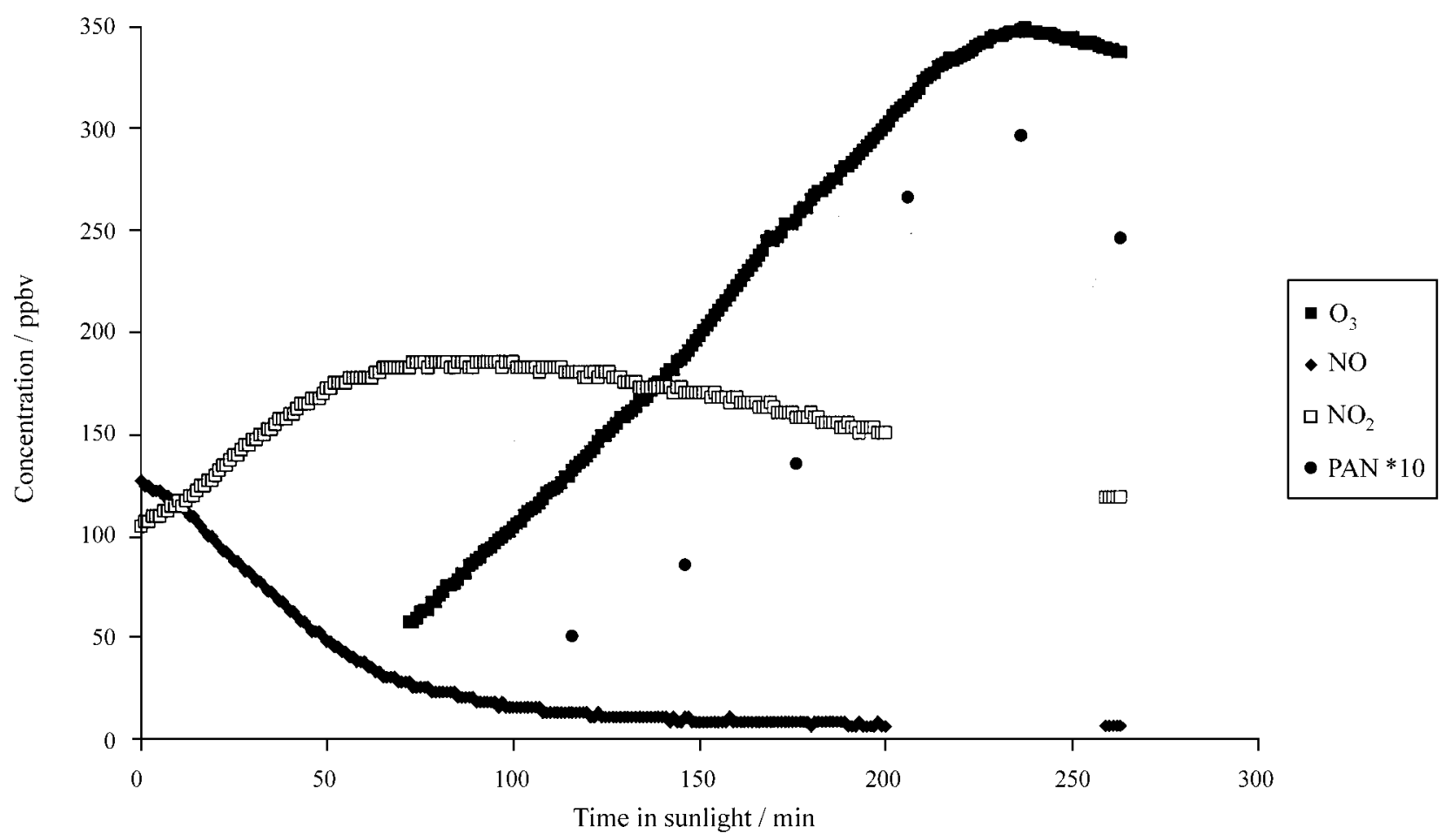

Figure 2. Concentrations of $\mathrm{NO}, \mathrm{NO}_{2}$, ozone and PAN in captive air experiment \#5 (April 15, 1997).

\section{Nature and ambient concentrations of VOC precursors}

Listed in Table 2 are the initial concentrations of the $c a$. 75 VOC that were measured by GC-FID analysis of the ambient air collected in canister samples at the beginning of the experiments. On a mass concentration basis, the most abundant compounds (after $\mathrm{CO}, \mathrm{CO}_{2}$ and methane) were ethylene, acetylene, isopentane, MTBE, toluene, ethanol, $(\mathrm{m}+\mathrm{p})$-xylene, formaldehyde and acetaldehyde.

The canister samples were also analyzed by GC-MS. An example of GC-MS chromatogram is given in Fig. 3 for the sample collected in experiment \#5. These analyses enabled us to verify the structure of the VOC that were identified and measured by GC-FID. In addition, GC-MS analysis resulted in the identification of additional VOC. The 30 additional compounds identified by GC-MS are listed in Table 3 . These compounds included 3 fluorocarbons, 12 hydrocarbons $\left(\mathrm{C}_{6}-\mathrm{C}_{12}\right.$ alkanes, alkenes and aromatics), 10 carbonyls ( 8 aldehydes and 2 ketones) and 5 other compounds: carbonyl sulfide, carbon disulfide, nitromethane, methyl formate and acetic acid.

\section{Photochemical production of aldehydes}

In a captive air experiment, formaldehyde and acetaldehyde initially present are rapidly removed by photolysis and by reaction with the hydroxyl $\operatorname{radical}(\mathrm{OH})$. At the same time, the two aldehydes are formed as oxidation products of many of the VOC initially present. In turn, a fraction of the aldehydes thus formed is removed by photolysis and by reaction with $\mathrm{OH}$. This competition between photochemical formation and photochemical removal may result in a net production or a net loss of formaldehyde and acetaldehyde. Initial and final concentrations of formaldehyde and acetaldehyde are compared in Table 4 . The data in Table 4 clearly indicate net production of both aldehydes in all six captive air experiments. These results are consistent with the data given in Table 2 for VOC, virtually all of which (including MTBE) are precursors to formaldehyde and a number of which (including ethanol) are precursors to acetaldehyde. Net production of formaldehyde ranged from 20 to $46 \mathrm{ppb}$, net production of acetaldehyde ranged from 25 to $39 \mathrm{ppb}$, and concentration ratios (final / initial) were $c a$. 2.3-3.3 for formaldehyde and $c a$. 2.0-4.8 for acetaldehyde.

In fact, the data given in Table 4 are likely to be lower limits for actual net production of aldehydes, and this for two reasons. First, measured final concentrations may be lower than actual values if loss of aldehydes to the chamber wall becomes important late in the experiments ${ }^{11-13}$. This is because the volume of the Teflon chamber decreases and the chamber surface-to-volume $(\mathrm{S} / \mathrm{V})$ ratio correspondingly increases as air is withdrawn from the chamber for the purpose of measuring $\mathrm{NO}_{\mathrm{x}}$, ozone and PAN: this increase in $\mathrm{S} / \mathrm{V}$ may lead to an increase in the rate of loss of aldehydes to the chamber walls. Second, the samples collected when levels of ozone are high may suffer from a negative bias due to reaction of ozone with the DNPH derivatives of formaldehyde and acetaldehyde during sam- 
Table 1. Summary of initial concentrations, maximum ozone concentrations and other relevant parameters for captive air experiments carried out in downtown Porto Alegre, RS, April 1997.

\begin{tabular}{|c|c|c|c|c|c|c|}
\hline Experiment number & 1 & 2 & 3 & 4 & 5 & 6 \\
\hline Date (1997) & April 8 & April 9 & April 10 & April 14 & April 15 & April 16 \\
\hline Start time (local time) & $9: 25$ & $9: 16$ & $9: 21$ & $9: 25$ & $9: 05$ & 9:06 \\
\hline \multicolumn{7}{|l|}{ Initial concentrations } \\
\hline nitric oxide, $\mathrm{ppb}$ & 133 & 113 & 68 & 153 & 125 & 50 \\
\hline nitrogen dioxide, $\mathrm{ppb}$ & 75 & 45 & 50 & 58 & 108 & 60 \\
\hline carbon monoxide, $\mathrm{ppb}$ & 5872 & 3115 & 2402 & 4369 & 6503 & 4164 \\
\hline carbon dioxide, $\mathrm{ppm}$ & 416 & 398 & 404 & 443 & 453 & 399 \\
\hline formaldehyde, $\mathrm{ppb}$ & 15.6 & 11.5 & 10.8 & 18.8 & 22.4 & 15.4 \\
\hline acetaldehyde, $\mathrm{ppb}$ & 17.6 & 10.2 & 15.1 & 18.0 & 31.3 & 14.2 \\
\hline MTBE, ppb & 9.9 & 5.7 & 3.0 & 9.8 & 17.1 & 9.3 \\
\hline ethanol, ppb & no data & 15.2 & 11.7 & 31.2 & 68.2 & 31.8 \\
\hline methane, ppb & 2898 & 1648 & 1755 & 1910 & 5685 & 1639 \\
\hline total non-methane hydrocarbons (a) & 764 & 499 & 276 & 997 & 1194 & 810 \\
\hline alkanes (a) & 170 & 123 & 74 & 174 & 295 & 161 \\
\hline alkenes (a) & 169 & 105 & 69 & 242 & 255 & 156 \\
\hline aromatics (a) & 119 & 72 & 43 & 137 & 179 & 97 \\
\hline maximum ozone, ppb (b) & 185 & 248 & 223 & 292 & 348 & 156 \\
\hline maximum PAN, ppb (b) & 17.5 & 19.9 & 18.5 & 27.5 & 29.5 & 13.3 \\
\hline
\end{tabular}

(a) in units of micrograms per cubic meter.

(b) initial concentrations of ozone and PAN were below detection in all experiments.

pling, and thus measured values may be lower limits for actual concentrations.

\section{PAN / ozone concentration ratios}

The maximum PAN / maximum ozone concentration ratios listed in Table 1 are $c a$. 0.08-0.09. Since the thermal decomposition of PAN increases rapidly with increasing temperature ${ }^{15}$, and since the temperature in the chamber after several hours in sunlight (i.e., when ozone and PAN reach high levels) is higher than the ambient temperature by $c a .5^{\circ} \mathrm{C}$, the maximum PAN concentrations and the maximum PAN / maximum ozone concentration ratios measured in the captive air experiments are probably lower limits for actual values. The $\mathrm{PAN} / \mathrm{O}_{3}$ ratios measured in this study are higher than those typically measured in other urban areas ${ }^{15}$ and are comparable to those measured during photochemical smog episodes in Southern California ${ }^{15}$. A major precursor to PAN is acetaldehyde, which is an abundant component of emissions from vehicles that use ethanol fuel.
Ranking of VOC with respect to photochemical formation of ozone

It is of interest to examine the relative contribution of the VOC listed in Table 2 to photochemical formation of ozone in the captive air experiments. This can be done by ranking the $\mathrm{VOC}$ according to their ability to react with the hydroxyl radical (all VOC react with $\mathrm{OH}$, leading to photochemically reactive products including free radicals). VOC can also be ranked with respect to their ability to produce ozone. To rank VOC with respect to reaction with $\mathrm{OH}$, we calculate the product of the VOC concentration and of the VOC-OH reaction rate constant:

$$
\mathrm{OH} \text { removal by } \mathrm{VOC} \equiv[\mathrm{VOC}] \times \mathrm{kOH}_{\mathrm{OH}}
$$

To rank VOC with respect to ozone formation, we calculate the product of the VOC concentration and the VOC maximum incremental reactivity coefficient $(\mathrm{MIR}=$ grams of ozone formed per gram of VOC):

ozone produced by $\mathrm{VOC} \equiv[\mathrm{VOC}] \times \mathrm{MIR}$ 
Table 2. VOC and their initial concentrations (microgram per cubic meter) in captive air experiments.

\begin{tabular}{|c|c|c|c|c|c|c|}
\hline \multirow[t]{2}{*}{ Compound } & \multicolumn{6}{|c|}{ Experiment \# (a) } \\
\hline & 1 & 2 & 3 & 4 & 5 & 6 \\
\hline methane & 1904 & 1083 & 1153 & 1255 & 3735 & 1077 \\
\hline ethane & 6.0 & 4.5 & 3.5 & 8.3 & 8.6 & 5.5 \\
\hline ethylene & 37.6 & 23.2 & 17.8 & 79.2 & 48.7 & 29.2 \\
\hline acetylene & 58.1 & 31.4 & 23.4 & 60.3 & 86.0 & 54.8 \\
\hline propane & 15.3 & 14.0 & 7.8 & 8.0 & 43.6 & 18.1 \\
\hline propene & 12.5 & 7.5 & 5.6 & 24.9 & 18.6 & 10.5 \\
\hline i-butane & 6.2 & 7.9 & 3.0 & 1.9 & 18.0 & 7.4 \\
\hline i-butene & 9.5 & 7.0 & 4.7 & 9.6 & 14.6 & 8.0 \\
\hline 1-butene & 3.5 & 2.5 & 1.9 & 3.5 & 6.5 & 3.5 \\
\hline 1,3-butadiene & 2.6 & 2.5 & 1.3 & 7.5 & 3.5 & 2.8 \\
\hline n-butane & 11.7 & 13.1 & 5.0 & 5.1 & 31.3 & 14.6 \\
\hline trans-2-butene & 3.2 & 2.8 & 1.2 & 3.1 & 6.2 & 2.6 \\
\hline \multicolumn{7}{|l|}{ 2,2-dimethylpropane } \\
\hline cis-2-butene & 2.5 & 1.7 & 1.0 & 2.8 & 5.7 & 2.2 \\
\hline 3-methyl-1-butene & 1.1 & 1.2 & 0.6 & 1.3 & 1.9 & 0.4 \\
\hline i-pentane & 24.6 & 14.4 & 11.0 & 31.7 & 40.8 & 25.1 \\
\hline 1-pentene & 3.2 & 1.9 & 1.3 & 3.4 & 5.1 & 3.1 \\
\hline 2-methyl-1-butene & 5.3 & 3.2 & 1.8 & 6.4 & 9.0 & 5.8 \\
\hline n-pentane & 13.9 & 8.7 & 6.0 & 14.8 & 23.1 & 13.7 \\
\hline isoprene & 1.0 & 1.4 & 0.4 & 1.6 & 0.7 & 1.9 \\
\hline trans-2-pentene & 6.0 & 3.8 & 1.9 & 7.8 & 10.9 & 6.9 \\
\hline cis-2-pentene & 3.5 & 2.0 & 1.2 & 4.1 & 5.4 & 3.7 \\
\hline 2-methyl-2-butene & 7.4 & 4.8 & 2.1 & 10.2 & 12.0 & 8.3 \\
\hline 2,2-dimethylbutane & 1.4 & 0.8 & 0.2 & 1.0 & 1.2 & 0.6 \\
\hline cyclopentene & 3.4 & 2.2 & 1.0 & 5.6 & 6.3 & 4.3 \\
\hline 4-methyl-1-pentene & 1.6 & 1.0 & 0.2 & 1.5 & 2.5 & 1.5 \\
\hline cyclopentane & 2.8 & 1.7 & 1.1 & 3.3 & 4.9 & 2.9 \\
\hline 2,3-dimethylbutane & 1.7 & 1.1 & 0.7 & 1.7 & 2.7 & 1.5 \\
\hline \multicolumn{7}{|l|}{ cis-4-methyl-2-pentene } \\
\hline 2-methylpentane & 10.3 & 6.8 & 4.4 & 12.0 & 12.0 & 9.6 \\
\hline 3-methylpentane & 5.5 & 3.5 & 3.5 & 8.3 & 8.0 & 4.7 \\
\hline 2-methyl-1-pentene & 1.1 & 0.7 & 0.3 & 1.4 & 2.0 & 1.1 \\
\hline 1-hexene & 1.2 & 0.7 & 0.4 & 1.3 & 2.0 & 1.0 \\
\hline n-hexane & 8.2 & 5.8 & 4.1 & 18.0 & 11.8 & 6.6 \\
\hline trans-2-hexene & 1.8 & 1.1 & 0.4 & 2.5 & 2.6 & 1.7 \\
\hline 2-methyl-2-pentene & 2.3 & 1.4 & 0.3 & 2.8 & 2.9 & 2.0 \\
\hline cis-2-hexene & 0.9 & 0.6 & 0.2 & 1.1 & 1.4 & 0.9 \\
\hline methylcyclopentane & 8.1 & 5.9 & 4.1 & 9.5 & 12.0 & 7.5 \\
\hline 2,4-dimethylpentane & 1.1 & 0.8 & 0.3 & 1.1 & 1.3 & 0.8 \\
\hline MTBE & 35.8 & 20.5 & 10.7 & 35.1 & 61.7 & 33.3 \\
\hline
\end{tabular}


Table 2. (Cont.)

\begin{tabular}{|c|c|c|c|c|c|c|}
\hline benzene & 16.8 & 10.4 & 7.3 & 25.6 & 24.4 & 15.1 \\
\hline cyclohexane & 3.4 & 2.6 & 1.4 & 3.9 & 3.9 & 3.2 \\
\hline 2-methylhexane & 4.5 & 2.8 & 1.4 & 4.1 & 6.3 & 3.7 \\
\hline 2,3-dimethylpentane & 1.9 & 1.1 & 0.8 & 1.1 & 3.1 & 1.6 \\
\hline 3-methylhexane & 5.2 & 3.2 & 1.9 & 4.7 & 7.5 & 4.4 \\
\hline 2,2,4-trimethylpentane & 2.1 & 1.3 & 0.7 & 2.1 & 3.2 & 1.8 \\
\hline n-heptane & 7.0 & 4.4 & 2.3 & 6.8 & 9.4 & 5.7 \\
\hline \multicolumn{7}{|l|}{ 2,4,4-trimethyl-1-pentene } \\
\hline methylcyclohexane & 6.6 & 4.6 & 2.3 & 6.2 & 9.1 & 5.3 \\
\hline \multicolumn{7}{|l|}{ 2,4,4-trimethyl-2-pentene } \\
\hline 2,5-dimethylhexane & 1.7 & 1.1 & 0.5 & 1.6 & 2.5 & 1.4 \\
\hline 2,4-dimethylhexane & 0.8 & 0.5 & 0.2 & 0.7 & 1.1 & 0.6 \\
\hline 2,3,4-trimethylpentane & 0.8 & 0.6 & 0.2 & 1.1 & 0.9 & 0.6 \\
\hline toluene & 30.5 & 19.6 & 11.7 & 33.7 & 45.7 & 22.1 \\
\hline 2,3-dimethylhexane & 0.4 & 0.4 & 0.2 & 0.4 & 0.7 & 0.3 \\
\hline 2-methylheptane & 3.2 & 2.2 & 1.2 & 3.2 & 4.7 & 2.5 \\
\hline 3-ethylhexane & 2.9 & 1.8 & 1.0 & 2.8 & 4.0 & 2.2 \\
\hline \multicolumn{7}{|l|}{ 2,2-dimethylheptane } \\
\hline \multicolumn{7}{|l|}{ 2,4,4-trimethylhexane } \\
\hline n-octane & 5.1 & 3.2 & 2.1 & 5.2 & 7.0 & 4.0 \\
\hline \multicolumn{7}{|l|}{ ethylcyclohexane } \\
\hline ethylbenzene & 9.4 & 5.2 & 2.8 & 7.4 & 14.2 & 6.7 \\
\hline m-xylene \& p-xylene & 21.2 & 12.8 & 6.6 & 20.8 & 30.9 & 17.2 \\
\hline styrene & & & & 6.2 & & \\
\hline o-xylene & 8.6 & 5.1 & 2.7 & 8.3 & 12.6 & 6.9 \\
\hline n-nonane & 3.6 & 2.3 & 1.8 & 3.0 & 5.7 & 2.5 \\
\hline \multicolumn{7}{|l|}{ i-propylbenzene } \\
\hline n-propylbenzene & 2.3 & 1.3 & 1.0 & 2.5 & 3.7 & 2.0 \\
\hline p-ethyltoluene & 7.4 & 4.4 & 2.6 & 11.1 & 14.4 & 8.1 \\
\hline m-ethyltoluene & 3.4 & 2.0 & 1.3 & 3.4 & 5.5 & 3.1 \\
\hline 1,3,5-trimethylbenzene & 4.2 & 2.4 & 1.6 & 3.7 & 6.0 & 3.2 \\
\hline o-ethyltoluene & 4.3 & 2.3 & 1.3 & 3.8 & 6.2 & 3.5 \\
\hline $\begin{array}{l}\text { 1,2,4-trimethylbenzene \& sec- } \\
\text { butylbenzene }\end{array}$ & 10.9 & 6.3 & 3.7 & 10.7 & 15.9 & 8.8 \\
\hline n-decane & 3.8 & 2.0 & 1.7 & 2.4 & 6.8 & 2.5 \\
\hline \multicolumn{7}{|l|}{ alpha-pinene } \\
\hline \multicolumn{7}{|l|}{ beta-pinene } \\
\hline \multicolumn{7}{|l|}{ delta-3-carene } \\
\hline d-limonene & & & & & & \\
\hline
\end{tabular}

(a) see Table 1 for experimental conditions and initial concentrations of oxides of nitrogen, carbon monoxide, carbon dioxide, ethanol, MTBE and aldehydes.

(b) a blank entry indicates that the compound was not detected (detection limit $=0.2$ micrograms per cubic meter). 
Although several reactivity scales can be used to rank VOC with respect to formation of ozone ${ }^{16}$, we select for the purpose of this study the MIR reactivity scale. This scale has been employed by the State of California in regulations that led to the specifications of California Phase II Reformulated Gasolines introduced in $1996^{16}$. The rate constants $\mathrm{k}_{\mathrm{OH}}$ used in Eq. 1 are from recent reviews of literature data $^{17}$. The MIR coefficients used in Eq. 2 are from Car$\operatorname{ter}^{16}$. For a few VOC listed in Table 2, rate constants and / or MIR coefficients were not available, and we estimated them from structure-reactivity considerations and from examination of photochemical oxidation mechanisms. The units employed are as follows: VOC concentrations in ppbv and $10^{12} \mathrm{x}$ rate constants in $\mathrm{cm}^{3}$ molecule $\mathrm{e}^{-1} \mathrm{~s}^{-1}$ for Eq. 1, and VOC concentrations in $\mu \mathrm{g} \mathrm{m}^{-3}$ and dimensionless MIR coefficient (gram ozone produced / gram VOC) in Eq. 2.

The results of the calculations made using Eq. 1 (reaction with $\mathrm{OH}$ ) and Eq. 2 (production of ozone) are listed in Table 5 for each VOC and each captive air experiment. These results are summarized in Table 6, which lists the 15

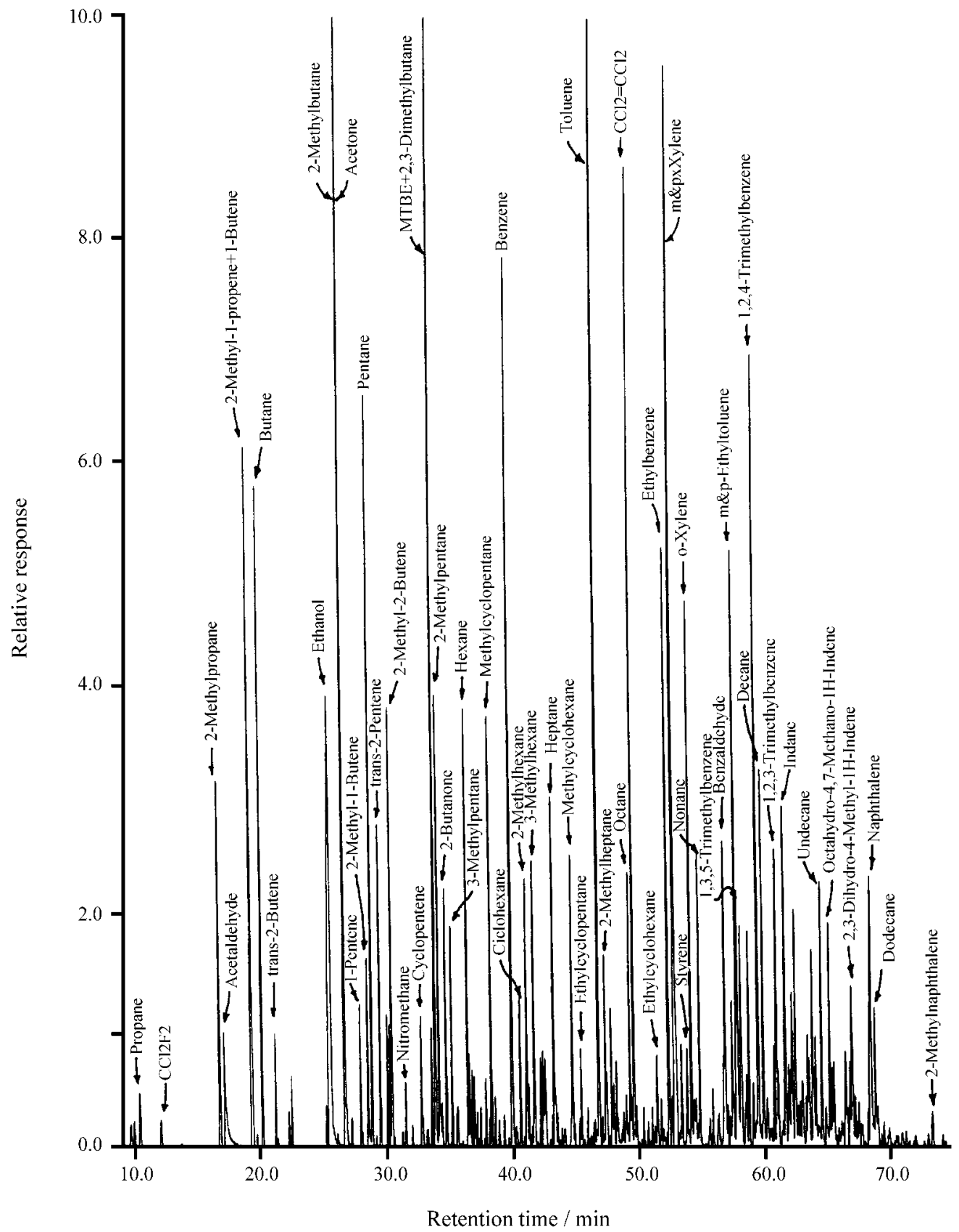

Figure 3. GC-MS chromatogram of a sample of ambient air collected at the beginning of captive air experiment $\#$. 
Table 3. Compounds identified by gas chromatography-mass spectrometry.

\begin{tabular}{lc}
\hline Hydrocarbons (a) & Carbonyls \\
\hline methylcyclopentene & acetaldehyde \\
ethylcyclopentane & acetone \\
styrene & propanal \\
propyl cyclohexane (b) & 2-butanone \\
3-methyloctane & hexanal \\
indane & heptanal \\
naphthalene & benzaldehyde \\
2-methylnaphthalene & octanal \\
undecane & nonanal \\
2,3-dihydro-4-methyl(IH)indene & decanal \\
octahydro-4,7-methano(IH)indene & \\
dodecane & Others \\
Fluorocarbons & carbonyl sulfide \\
F11 & carbon disulfide \\
F12 & nitromethane \\
F113 & methyl formate \\
\hline
\end{tabular}

(a) in addition to those listed in Table 2 .

(b) n-propyl and / or iso-propyl.

most important compounds with respect to reaction with $\mathrm{OH}$ and to production of ozone, and this for the average of the VOC data from the six captive air experiments. These results indicate that ranking according to photochemical reactivity is quite different from ranking according to con- centration, i.e., compare Table 6 and Table 2. With respect to reaction with $\mathrm{OH}$, carbon monoxide dominates followed by, in order of decreasing importance, ethylene, acetaldehyde, 2-methyl-2-butene, propene, isobutene, formaldehyde, trans-2-pentene, 2-methyl-1-butene, 1,3-butadiene, $(\mathrm{m}+\mathrm{p})$-xylene, cyclopentene, trans-2-butene, ethanol, and cis-2-pentene. MTBE is ranked \#27 and its contribution to reaction with $\mathrm{OH}$ is small, e.g. 10 times less than that of acetaldehyde and $c a .3$ times less than that of ethanol.

With respect to production of ozone, ethylene is ranked \#1, followed closely by carbon monoxide, followed by, in order of decreasing importance, acetaldehyde, $(m+p)$ xylene, formaldehyde, propene, 1,2,4-trimethylbenzene, toluene, ethanol, trans-2-pentene, p-ethyltoluene, oxylene, 2-methyl-2-butene, isobutene and 1,3-butadiene. MTBE is ranked \#30 and its contribution to ozone production is small, e.g. ca. 9 times less than that of acetaldehyde and $c a .3$ times less than that of ethanol. The data in Table 6 indicate that $\mathrm{CO}$, ethylene and acetaldehyde are the three most important contributors to both reaction with $\mathrm{OH}$ and production of ozone. Following these three compounds, alkenes (10 of which are ranked in the "top-15" compounds) make a significant contribution to reaction with $\mathrm{OH}$. These alkenes are also important with respect to ozone production, to which aromatic hydrocarbons also make a substantial contribution.

\section{Concluding Comments}

The results of the photochemical reactivity ranking calculations given in Table 5 and summarized in Table 6 underline the importance of carbon monoxide, alkenes and aromatics. An interesting implication in the case of $\mathrm{CO}$ is that control strategies aimed at reducing ambient levels of CO may also have a beneficial effect on ambient levels of ozone in the Porto Alegre area. Ethanol fuel plays a signifi-

Table 4. Net production of aldehydes in Porto Alegre captive air experiments.

\begin{tabular}{|c|c|c|c|c|c|c|}
\hline Experiment \# & 1 & 2 & 3 & 4 & 5 & 6 \\
\hline \multicolumn{7}{|l|}{ Formaldehyde } \\
\hline initial concentration, ppb (a) & 15.6 & 11.5 & 10.8 & 18.8 & 22.4 & 15.4 \\
\hline final concentration, $\mathrm{ppb}$ & 35.6 & 38.3 & 33.7 & 62.6 & 68.4 & 37.9 \\
\hline difference, $p p b(b)$ & +20.0 & +26.8 & +22.9 & +43.8 & +46.0 & +22.5 \\
\hline concentration ratio, final / initial & 2.28 & 3.33 & 3.13 & 3.34 & 3.05 & 2.46 \\
\hline \multicolumn{7}{|l|}{ Acetaldehyde } \\
\hline initial concentration, ppb (a) & 17.6 & 10.2 & 15.1 & 18.0 & 31.3 & 14.2 \\
\hline final concentration, $\mathrm{ppb}$ & 42.9 & 49.4 & 43.9 & 57.0 & 62.9 & 42.2 \\
\hline difference, $p p b(b)$ & +25.3 & +39.2 & +28.8 & +39.0 & +31.6 & +28.0 \\
\hline concentration ratio, final / initial & 2.44 & 4.84 & 2.91 & 3.17 & 2.01 & 2.97 \\
\hline
\end{tabular}

(a) from Table 1

(b) a "+" sign indicates net formation, see text. 
Table 5. Ranking of pollutants according to photochemical reactivity in captive air experiments \#1-6.

\begin{tabular}{|c|c|c|c|c|c|c|c|c|c|c|c|c|}
\hline \multirow[t]{2}{*}{ Compound } & \multicolumn{6}{|c|}{ ozone formation } & \multicolumn{6}{|c|}{ reaction with $\mathrm{OH}$} \\
\hline & $\# 1$ & $\# 2$ & $\# 3$ & $\# 4$ & $\# 5$ & $\# 6$ & $\# 1$ & $\# 2$ & $\# 3$ & $\# 4$ & $\# 5$ & $\# 6$ \\
\hline methane & 28.6 & 16.2 & 17.3 & 18.8 & 56.0 & 16.2 & 18.0 & 10.2 & 10.9 & 11.8 & 35.2 & 10.2 \\
\hline ethane & 1.5 & 1.1 & 0.9 & 2.1 & 2.2 & 1.4 & 1.2 & 0.9 & 0.7 & 1.7 & 1.8 & 1.1 \\
\hline ethylene & 278.2 & 171.7 & 131.7 & 586.1 & 360.4 & 216.1 & 279.4 & 172.4 & 132.3 & 588.5 & 361.9 & 217.0 \\
\hline acetylene & 29.1 & 15.7 & 11.7 & 30.2 & 43.0 & 27.4 & 42.6 & 23.0 & 17.1 & 44.2 & 63.0 & 40.1 \\
\hline propane & 7.3 & 6.7 & 3.7 & 3.8 & 20.9 & 8.7 & 9.5 & 8.7 & 4.8 & 5.0 & 27.1 & 11.3 \\
\hline propene & 117.5 & 70.5 & 52.6 & 234.1 & 174.8 & 98.7 & 191.1 & 114.7 & 85.6 & 380.8 & 284.4 & 160.6 \\
\hline i-butane & 7.5 & 9.6 & 3.6 & 2.3 & 21.8 & 9.0 & 5.7 & 7.3 & 2.8 & 1.8 & 16.6 & 6.8 \\
\hline i-butene & 50.4 & 37.1 & 24.9 & 50.9 & 77.4 & 42.4 & 212.9 & 156.9 & 105.3 & 215.2 & 327.2 & 179.3 \\
\hline 1-butene & 31.2 & 22.3 & 16.9 & 31.2 & 57.9 & 31.2 & 47.9 & 34.2 & 26.0 & 47.9 & 89.0 & 47.9 \\
\hline 1,3-butadiene & 28.3 & 27.3 & 14.2 & 81.8 & 38.2 & 30.5 & 78.3 & 75.3 & 39.2 & 225.9 & 105.4 & 84.3 \\
\hline n-butane & 11.9 & 13.4 & 5.1 & 5.2 & 31.9 & 14.9 & 12.0 & 13.5 & 5.1 & 5.2 & 32.2 & 15.0 \\
\hline trans-2-butene & 32.0 & 28.0 & 12.0 & 31.0 & 62.0 & 26.0 & 89.3 & 78.1 & 33.5 & 86.5 & 173.0 & 72.6 \\
\hline \multicolumn{13}{|l|}{ 2,2-dimethylpropane } \\
\hline cis-2-butene & 25.0 & 17.0 & 10.0 & 28.0 & 57.0 & 22.0 & 61.5 & 41.8 & 24.6 & 68.9 & 140.2 & 54.1 \\
\hline 3-methyl-1-butene & 6.8 & 7.4 & 3.7 & 8.1 & 11.8 & 2.5 & 12.2 & 13.3 & 6.7 & 14.4 & 21.1 & 4.4 \\
\hline i-pentane & 33.9 & 19.9 & 15.2 & 43.7 & 56.3 & 34.6 & 30.9 & 18.1 & 13.8 & 39.8 & 51.2 & 31.5 \\
\hline 1-pentene & 19.8 & 11.8 & 8.1 & 21.1 & 31.6 & 19.2 & 35.1 & 20.8 & 14.2 & 37.2 & 55.9 & 34.0 \\
\hline 2-methyl-1-butene & 26.0 & 15.7 & 8.8 & 31.4 & 44.1 & 28.4 & 112.8 & 68.1 & 38.3 & 136.2 & 191.5 & 123.4 \\
\hline n-pentane & 14.5 & 9.0 & 6.2 & 15.4 & 24.0 & 14.2 & 18.9 & 11.8 & 8.1 & 20.1 & 31.3 & 18.6 \\
\hline isoprene & 9.1 & 12.7 & 3.6 & 14.6 & 6.4 & 17.3 & 36.3 & 50.8 & 14.5 & 58.0 & 25.4 & 68.9 \\
\hline trans-2-pentene & 52.8 & 33.4 & 16.7 & 68.6 & 95.9 & 60.7 & 140.2 & 88.8 & 44.4 & 182.3 & 254.8 & 161.3 \\
\hline cis-2-pentene & 30.8 & 17.6 & 10.6 & 36.1 & 47.5 & 32.6 & 79.4 & 45.4 & 27.2 & 93.0 & 122.4 & 83.9 \\
\hline 2-methyl-2-butene & 47.4 & 30.7 & 13.4 & 65.3 & 76.8 & 53.1 & 224.3 & 145.5 & 63.7 & 309.2 & 363.8 & 251.6 \\
\hline 2,2-dimethylbutane & 1.1 & 0.7 & 0.2 & 0.8 & 1.0 & 0.5 & 0.9 & 0.5 & 0.1 & 0.7 & 0.8 & 0.4 \\
\hline cyclopentene & 26.2 & 16.9 & 7.7 & 43.1 & 48.5 & 33.1 & 81.8 & 52.9 & 24.1 & 134.7 & 151.6 & 103.5 \\
\hline 4-methyl-1-pentene & 9.9 & 6.2 & 1.2 & 9.3 & 15.5 & 9.3 & 14.0 & 8.7 & 1.7 & 13.1 & 21.8 & 13.1 \\
\hline cyclopentane & 6.7 & 4.1 & 2.6 & 7.9 & 11.8 & 7.0 & 4.9 & 3.0 & 1.9 & 5.8 & 8.6 & 5.1 \\
\hline 2,3-dimethylbutane & 1.8 & 1.2 & 0.7 & 1.8 & 2.9 & 1.6 & 2.8 & 1.8 & 1.1 & 2.8 & 4.4 & 2.5 \\
\hline \multicolumn{13}{|l|}{ cis-4-methyl-2-pentene } \\
\hline 2-methylpentane & 15.5 & 10.2 & 6.6 & 18.0 & 18.0 & 14.4 & 15.5 & 10.2 & 6.6 & 18.1 & 18.1 & 14.4 \\
\hline 3-methylpentane & 8.3 & 5.3 & 5.3 & 12.5 & 12.0 & 7.1 & 8.4 & 5.4 & 5.4 & 12.7 & 12.3 & 7.2 \\
\hline 2-methyl-1-pentene & 5.4 & 3.4 & 1.5 & 6.9 & 9.8 & 5.4 & 20.1 & 12.8 & 5.5 & 25.6 & 36.6 & 20.1 \\
\hline 1-hexene & 5.3 & 3.1 & 1.8 & 5.7 & 8.8 & 4.4 & 12.9 & 7.5 & 4.3 & 14.0 & 21.5 & 10.8 \\
\hline n-hexane & 8.0 & 5.7 & 4.0 & 17.6 & 11.6 & 6.5 & 12.7 & 9.0 & 6.3 & 27.9 & 18.3 & 10.2 \\
\hline trans-2-hexene & 12.1 & 7.4 & 2.7 & 16.8 & 17.4 & 11.4 & 35.1 & 21.4 & 7.8 & 48.7 & 50.6 & 33.1 \\
\hline 2-methyl-2-pentene & 14.7 & 9.0 & 1.9 & 17.9 & 18.6 & 12.8 & 59.5 & 36.2 & 7.8 & 72.4 & 75.0 & 51.7 \\
\hline cis-2-hexene & 6.0 & 4.0 & 1.3 & 7.4 & 9.4 & 6.0 & 17.0 & 11.3 & 3.8 & 20.8 & 26.5 & 17.0 \\
\hline methylcyclopentane & 22.7 & 16.5 & 11.5 & 26.6 & 33.6 & 21.0 & 14.1 & 10.3 & 7.2 & 16.6 & 20.9 & 13.1 \\
\hline 2,4-dimethylpentane & 1.7 & 1.2 & 0.5 & 1.7 & 2.0 & 1.2 & 1.3 & 1.0 & 0.4 & 1.3 & 1.6 & 1.0 \\
\hline MTBE & 22.2 & 12.7 & 6.6 & 21.8 & 38.3 & 20.6 & 28.1 & 16.1 & 8.4 & 27.6 & 48.5 & 26.2 \\
\hline benzene & 7.1 & 4.4 & 3.1 & 10.8 & 10.2 & 6.3 & 6.5 & 4.0 & 2.8 & 9.9 & 9.4 & 5.8 \\
\hline
\end{tabular}


Table 5. (Cont.)

\begin{tabular}{|c|c|c|c|c|c|c|c|c|c|c|c|c|}
\hline cyclohexane & 4.4 & 3.3 & 1.8 & 5.0 & 5.0 & 4.1 & 7.1 & 5.4 & 2.9 & 8.2 & 8.2 & 6.7 \\
\hline 2-methylhexane & 4.9 & 3.0 & 1.5 & 4.4 & 6.8 & 4.0 & 7.7 & 4.8 & 2.4 & 7.0 & 10.8 & 6.3 \\
\hline 2,3-dimethylpentane & 2.5 & 1.4 & 1.0 & 1.4 & 4.1 & 2.1 & 2.3 & 1.3 & 1.0 & 1.3 & 3.8 & 2.0 \\
\hline 3-methylhexane & 7.3 & 4.5 & 2.7 & 6.6 & 10.5 & 6.2 & 8.9 & 5.5 & 3.2 & 8.0 & 12.8 & 7.5 \\
\hline 2,2,4-trimethylpentane & 2.0 & 1.2 & 0.7 & 2.0 & 3.0 & 1.7 & 1.6 & 1.0 & 0.5 & 1.6 & 2.4 & 1.4 \\
\hline n-heptane & 5.7 & 3.6 & 1.9 & 5.5 & 7.6 & 4.6 & 12.0 & 7.5 & 3.9 & 11.7 & 16.1 & 9.8 \\
\hline \multicolumn{13}{|l|}{ 2,4,4-trimethyl-1-pentene } \\
\hline methylcyclohexane & 11.9 & 8.3 & 4.1 & 11.2 & 16.4 & 9.5 & 16.4 & 11.5 & 5.7 & 15.4 & 22.7 & 13.2 \\
\hline \multicolumn{13}{|l|}{ 2,4,4-trimethyl-2-pentene } \\
\hline 2,5-dimethylhexane & 2.7 & 1.8 & 0.8 & 2.6 & 4.0 & 2.2 & 1.8 & 1.2 & 0.5 & 1.7 & 2.7 & 1.5 \\
\hline 2,4-dimethylhexane & 1.2 & 0.8 & 0.3 & 1.1 & 1.7 & 0.9 & 0.9 & 0.5 & 0.2 & 0.7 & 1.2 & 0.6 \\
\hline 2,3,4-trimethylpentane & 1.3 & 1.0 & 0.3 & 1.8 & 1.4 & 1.0 & 1.2 & 0.9 & 0.3 & 1.7 & 1.4 & 0.9 \\
\hline toluene & 82.4 & 52.9 & 31.6 & 91.0 & 123.4 & 59.7 & 48.3 & 31.0 & 18.5 & 53.3 & 72.3 & 35.0 \\
\hline 2,3-dimethylhexane & 0.5 & 0.5 & 0.3 & 0.5 & 0.9 & 0.4 & 0.4 & 0.4 & 0.2 & 0.4 & 0.7 & 0.3 \\
\hline 2-methylheptane & 3.1 & 2.1 & 1.2 & 3.1 & 4.5 & 2.4 & 6.0 & 4.1 & 2.2 & 6.0 & 8.8 & 4.7 \\
\hline 3-ethylhexane & 3.5 & 2.2 & 1.2 & 3.4 & 4.8 & 2.6 & 5.4 & 3.4 & 1.9 & 5.2 & 7.5 & 4.1 \\
\hline \multicolumn{13}{|l|}{ 2,2-dimethylheptane } \\
\hline \multicolumn{13}{|l|}{ 2,4,4-trimethylhexane } \\
\hline n-octane & 3.1 & 1.9 & 1.3 & 3.1 & 4.2 & 2.4 & 9.5 & 6.0 & 3.9 & 9.7 & 13.1 & 7.5 \\
\hline \multicolumn{13}{|l|}{ ethylcyclohexane } \\
\hline ethylbenzene & 25.4 & 14.0 & 7.6 & 20.0 & 38.3 & 18.1 & 15.4 & 8.5 & 4.6 & 12.1 & 23.2 & 11.0 \\
\hline m-xylene \& p-xylene & 173.8 & 105.0 & 54.1 & 170.6 & 253.4 & 141.0 & 115.3 & 69.6 & 35.9 & 113.1 & 168.0 & 93.5 \\
\hline \multicolumn{13}{|l|}{ styrene } \\
\hline o-xylene & 55.9 & 33.2 & 17.6 & 54.0 & 81.9 & 44.9 & 27.1 & 16.1 & 8.5 & 26.2 & 39.8 & 21.8 \\
\hline n-nonane & 1.9 & 1.2 & 1.0 & 1.6 & 3.1 & 1.4 & 6.9 & 4.4 & 3.4 & 5.7 & 10.9 & 4.8 \\
\hline \multicolumn{13}{|l|}{ i-propylbenzene } \\
\hline n-propylbenzene & 4.8 & 2.7 & 2.1 & 5.3 & 7.8 & 4.2 & 2.8 & 1.6 & 1.2 & 3.1 & 4.5 & 2.4 \\
\hline p-ethyltoluene & 48.8 & 29.0 & 17.2 & 73.3 & 95.0 & 53.5 & 18.2 & 10.8 & 6.4 & 27.3 & 35.5 & 19.9 \\
\hline m-ethyltoluene & 27.9 & 16.4 & 10.7 & 27.9 & 45.1 & 25.4 & 13.3 & 7.8 & 5.1 & 13.3 & 21.5 & 12.1 \\
\hline 1,3,5-trimethylbenzene & 42.4 & 24.2 & 16.2 & 37.4 & 60.6 & 32.3 & 49.1 & 28.1 & 18.7 & 43.3 & 70.2 & 37.4 \\
\hline o-ethyltoluene & 28.0 & 15.0 & 8.5 & 24.7 & 40.3 & 22.8 & 10.8 & 5.8 & 3.3 & 9.5 & 15.5 & 8.8 \\
\hline \multicolumn{13}{|l|}{ 1,2,4-trimethylbenzene } \\
\hline$\&$ sec-butylbenzene & 95.9 & 55.4 & 32.6 & 94.2 & 139.9 & 77.4 & 72.1 & 41.7 & 24.5 & 70.8 & 105.2 & 58.2 \\
\hline n-decane & 1.7 & 0.9 & 0.8 & 1.1 & 3.1 & 1.2 & 7.3 & 3.9 & 3.3 & 4.6 & 13.1 & 4.8 \\
\hline \multicolumn{13}{|l|}{ alpha-pinene } \\
\hline \multicolumn{13}{|l|}{ beta-pinene } \\
\hline \multicolumn{13}{|l|}{ delta-3-carene } \\
\hline \multicolumn{13}{|l|}{ d-limonene } \\
\hline ethanol & & 38.4 & 29.5 & 78.8 & 172.1 & 80.3 & & 49.7 & 38.3 & 102.0 & 223.0 & 104.0 \\
\hline formaldehyde & 138.0 & 101.7 & 95.5 & 166.3 & 198.1 & 136.2 & 152.4 & 112.4 & 105.5 & 183.7 & 218.8 & 150.5 \\
\hline acetaldehyde & 174.4 & 101.1 & 149.6 & 178.4 & 310.2 & 140.7 & 278.1 & 161.2 & 238.6 & 284.4 & 494.5 & 224.4 \\
\hline carbon monoxide & 363.6 & 192.9 & 148.7 & 270.5 & 402.6 & 257.8 & 1409.3 & 747.6 & 576.5 & 1048.6 & 1560.7 & 999.4 \\
\hline
\end{tabular}


Table 6. Ranking of "top-15" pollutants with respect to reaction with $\mathrm{OH}$ and production of ozone. (average of 6 captive air experiments).

\begin{tabular}{|c|c|c|c|c|c|}
\hline \multicolumn{3}{|c|}{ reaction with $\mathrm{OH}$} & \multicolumn{3}{|c|}{ production of ozone } \\
\hline rank & compound & Eq. 1 (a) & rank & compound & Eq. 2 (a) \\
\hline 1 & $\mathrm{CO}$ & 1057 & 1 & ethylene & 292 \\
\hline 2 & ethylene & 292 & 2 & $\mathrm{CO}$ & 273 \\
\hline 3 & acetaldehyde & 260 & 3 & acetaldehyde & 176 \\
\hline 4 & 2-methyl-2-butene & 226 & 4 & $(\mathrm{~m}+\mathrm{p})$-xylene & 150 \\
\hline 5 & propene & 203 & 5 & formaldehyde & 139 \\
\hline 6 & isobutene & 200 & 6 & propene & 125 \\
\hline 7 & formaldehyde & 154 & 7 & 1,2,4-trimethylbenzene & 83 \\
\hline 8 & trans-2-pentene & 145 & 8 & toluene & 73 \\
\hline 9 & 2-methyl-1-butene & 112 & 9 & ethanol & 66 \\
\hline 10 & 1,3-butadiene & 101 & 10 & trans-2-pentene & 55 \\
\hline 11 & $(m+p)$-xylene & 99 & 11 & p-ethyltoluene & 53 \\
\hline 12 & cyclopentene & 91 & 12 & o-xylene & 48 \\
\hline 13 & trans-2-butene & 89 & 13 & 2-methyl-2-butene & 48 \\
\hline 14 & ethanol & 86 & 14 & isobutene & 47 \\
\hline 15 & cis-2-pentene & 75 & 15 & 1,3-butadiene & 37 \\
\hline 27 & MTBE & 26 & 30 & MTBE & 20 \\
\hline
\end{tabular}

(a) see Eq. 1, Eq. 2 and units for numerical values in the text.

cant role, due to emissions of unburned ethanol (ranked \#9 for ozone production and \#14 for reaction with $\mathrm{OH}$ ) and also due to acetaldehyde emissions from ethanol-fueled vehicles (acetaldehyde ranks \#3 for ozone production and \#3 for reaction with $\mathrm{OH}$ ). In contrast, the results in Table 5 and Table 6 indicate a negligible role for MTBE as a photochemical precursor to the formation of ozone in the atmosphere of Porto Alegre.

\section{Acknowledgments}

This study has been sponsored by PETROBRAS, Rio de Janeiro, CENPES Project 040562. The VOC analyses were carried out by Prof. R. A. Rasmussen and his co-workers, Dpt. of Environmental Science and Engineering, Oregon Graduate Institute of Science and Technology, Portland, OR, USA. Aldehyde samples were analyzed by Prof. Maria Teresa Raya Rodriguez and her co-workers, Centro de Ecologia, Universidade Federal de Rio Grande do Sul, Porto Alegre, RS, Brazil. We also thank Mr. Nilce O. Costa (CENPES) and Mr. Leonardo F. Souza (CENPES) for their support and for technical discussions.

\section{References}

1. U.S. National Research Council, Rethinking the ozone problem in urban and regional air pollution. National Academy Press, Washington, D.C. (1991).
2. Grosjean, E.; Rasmussen, R.A.; Grosjean, D. Atmos. Environ. 1998, 32, in press.

3. Grosjean, E.; Grosjean, D.; Gunawardena, R.; Rasmussen, R.A. Environ. Sci. Technol. 1998, 32, 736.

4. Seinfeld, J.H. J. Air Pollut. Control Assoc. 1988, 38, 616.

5. Pimentel, A.S.; Arbilla, G. Química Nova 1997, 20, 252.

6. Kelly, N.A. J. Air Pollut. Control Assoc. 1981, 31, 565.

7. Kelly, N.A. J. Air Pollut. Control Assoc. 1985, 35, 27.

8. Grosjean, D.; Lloyd, A.; Countess, R.J.; Lurmann, F.; Fung, K. In Captive Air Experiments in Support of Photochemical Kinetic Model Evaluation, Phase I. ERT report P-A764-500, Environmental Research and Technology, Inc., Westlake Village, California (1982).

9. Kelly, N.A.; Gunst, R.F. In Response of Ozone to Changes in Hydrocarbon and Nitrogen Oxide Concentrations in Outdoor Chambers Filled with Los Angeles Air. GM report GRM - 6668 / ENV \#269, General Motors Research Laboratories, Warren, Michigan (1989).

10. Shibuya, K.; Nagashima, T.; Imai, S.; Akimoto, H. Environ. Sci. Technol. 1981, 15, 661.

11. Grosjean, D. Environ. Sci. Technol. 1985, 19, 1059. 
12. McMurry, P.H.; Grosjean, D. Environ. Sci. Technol. 1985, 19, 1176.

13. Grosjean, E.; Grosjean, D. Int. J. Chem. Kinetics 1996, $28,911$.

14. Grosjean, E.; Grosjean, D.; Fraser, M.P.; Cass, G.R. Environ Sci. Technol. 1996, 30, 2687.
15. Grosjean, E.; Grosjean, D.; Fraser, M.P.; Cass, G.R. Environ. Sci. Technol. 1996, 30, 2704.

16. Carter, W.P.L. J. Air Waste Manag. Assoc. 1994, 44, 881.

17. Atkinson, R. J. Phys. Chem. Ref. Data 1997, 26, 215. 